\begin{tabular}{|l|l|l|l|l|}
\hline Jurnal Penelitian \& PKM & Juli 2017 & Vol 4, No: 2 & Hal: $129-389$ & ISSN \\
\hline
\end{tabular}

\title{
PERAN GANDA BURUH PEREMPUAN SEKTOR INDUSTRI DALAM KELUARGA
}

\author{
OLEH: \\ ARISTYA RAHMAHARYATI M., BUDHI WIBHAWA, R. NUNUNG NURWATI \\ 1. Mahasiswa Program Studi Sarjana (S-1) Ilmu Kesejahteraan Sosial Fakultas IImu Sosial dan IImu Politik \\ Universitas Padjadjaran \\ 2. Pusat Studi Kewirausahaan Sosial, CSR dan Pengembangan Masyarakat Fakultas IImu Sosial dan IImu \\ Politik Universitas Padjadjaran \\ 3. Mahasiswa Program Studi Sarjana (S-1) Ilmu Kesejahteraan Sosial Fakultas IImu Sosial dan Ilmu Politik \\ Universitas Padjadjaran
}

(aristyarahma06@gmail.com)

\begin{abstract}
ABSTRAK
Keterlibatan buruh perempuan dalam sektor industri tidak sedikitnya karena diakibatkan masalah ekonomi. Dalam hal tersebut, buruh perempuan dihadapkan dengan dua tuntutan peran yaitu sebagai ibu rumah tangga dan pencari nafkah yang keduanya menuntut kewajiban dan tanggung jawab untuk dilakukan secara bersamaan. Seringkali buruh perempuan mengalami dilema atas dua peran tersebut, perasaan bersalah kerapkali muncul ketika dihadapkan dengan situasi yang mengharuskan keberadaannya dalam keluarga. Namun disisi lain terikat oleh jam kerja yang panjang dan tidak teratur membuat buruh perempuan sulit mengatur tugas dalam keluarga. Karna sebagian besar waktu buruh perempuan dihabiskan di tempat kerja untuk mengejar target produksi pabrik industri. Hal tersebut akan menimbulkan konfik-konflik dalam diri perempuan maupun keluarga. Tak jarang diantara buruh perempuan mengalami stres, emosi serta gangguan kesehatan. Selain itu tak jarang menimbulkannya konflik dalam keluarga, mengalami perselisihan dengan anggota keluarga serta komunikasi tidak berjalan dengan baik. Akibat dari buruh perempuan tidak dapat melaksanakan peran-perannya, maka tidak menutup kemungkinan akan menimbulkan permasalahan. Dalam kesempatan ini pekerja sosial berperan untuk membantu buruh perempuan dalam hal meningkatkan kemampuan menjalankan perannya, memperbaiki relasi buruh perempuan dengan anggota keluarganya, memperbaiki komunikasi antar anggota keluarga serta mampu mengatasi masalah yang timbul dalam keluarga. Selain itu pekerja sosial dapat mengkaji kebijakan dari pemerintah mengenai jam kerja khususnya untuk perempuan.
\end{abstract}

Kata kunci: Masalah ekonomi, peran ganda, konflik, jam kerja, peran buruh

\section{PENDAHULUAN}

Seiring dengan meningkatnya pembangunan industri disetiap daerah, memicu seseorang untuk memperbaiki kehidupan dan meningkatkan kualitas hidup. Bersamaan dengan hal tersebut peran perempuan dalam kehidupan terus berubah, salah satunya yaitu peran perempuan dalam meningkatkan kesejahteraan keluarga. Kini banyak perempuan yang berpartisipasi aktif bekerja di sektor publik untuk membantu memenuhi kebutuhan ekonomi keluarga, adapun data perempuan yang bekerja di sektor industri di Kabupaten Subang sebagai berikut:

Data menunjukkan bahwa dari 598 Perusahaan yang terdaftar di Dinas Tenaga Kerja Kabupaten Subang Tahun 2014, sebanyak 21 perusahaan bergerak dalam industri garmen dan menyerap kurang lebih 36.504 orang dari total tenaga kerja terserap sebanyak 84.148 orang. Dari 
total buruh dalam industri garmen tersebut, $84 \%$ adalah buruh perempuan dan hanya $16 \%$ buruh laki-laki. Berdasarkan data tersebut bahwa di Kabupaten Subang, jumlah buruh perempuan lebih banyak daripada jumlah buruh laki-laki.

Terdapat beberapa faktor pendorong keterlibatan perempuan dalam sektor industri yaitu dikarenakan tekanan ekonomi atau kebutuhan ekonomi keluarga yang semakin tak terjangkau, suami tidak bekerja, serta menambah pendapatan suami. Selain itu, rata-rata perempuan yang bekerja di sektor industri merupakan golongan ekonomi menengah ke bawah yang tingkat pendidikan dan keahliannya masih rendah. Selain itu, menurut (Suleeman, 1995) terjadinya ketidaksetaraan gender dalam pendidikan dimana adanya perbedaan dalam hak dan kewajiban perempuan dan laki-laki dalam mengecap pendidikan formal. Adapun data tingkat pendidikan perempuan di Kabupaten Subang adalah sebagai berikut:

Tabel 1.1 Jumlah Pencari Kerja yang Terdaftar menurut Jenis Kelamin dan Tingkat Pendidikan yang Ditamatkan

\begin{tabular}{|c|c|c|}
\hline $\begin{array}{c}\text { Tingkat } \\
\text { Pendidikan }\end{array}$ & $\begin{array}{c}\text { Laki- } \\
\text { laki }\end{array}$ & Perempuan \\
\hline $\begin{array}{c}\text { Tamat Sekolah } \\
\text { Dasar }\end{array}$ & 185 & 910 \\
\hline $\begin{array}{c}\text { Tamat SLTP dan } \\
\text { Sederajat }\end{array}$ & 902 & 2263 \\
\hline $\begin{array}{c}\text { Tamat SLTA dan } \\
\text { Sederajat }\end{array}$ & 2.053 & 1.891 \\
\hline $\begin{array}{c}\text { Tamat Sekolah } \\
\text { Menengah Kejuruan }\end{array}$ & 2.194 & 1.421 \\
\hline
\end{tabular}

Sumber : Dinas Tenaga Kerja dan Transmigrasi Kabupaten Subang https://subangkab.bps.go.id LlinkTabelStatis/view/id/30 diakses pada 26 Maret 2017.

Berdasarkan tabel 1.1 bahwa tingkat pendidikan perempuan lebih rendah dibandingkan tingkat pendidikan laki-laki. Melalui tabel diatas, menunjukan bahwa jumlah tamatan SLTA perempuan sebanyak 1.891 orang sedangkan jumlah laki-laki yang tamat SLTA 2.053 orang.
Buruh perempuan yang bekerja di sektor industri akan dihadapkan dengan dua tuntutan peran, yaitu sebagai ibu rumah tangga dan sebagai pencari nafkah. Kedua peran tersebut merupakan kewajiban dan tanggung jawab yang harus dilakukan secara bersamaan dengan optimal. Namun seringkali keadaan tersebut menimbulkan konflik yang cukup berat dari dalam diri seorang buruh perempuan. Beberapa konflik yang dialami buruh perempuan biasanya terkait pekerjaan dan keluarga. Seringkali buruh perempuan memiliki tekanan dalam keluarga yang mempengaruhi pekerjaan misalnya kehadiran anak yang masih kecil, lemahnya dukungan dari keluarga serta konflik keluarga. Selain itu dalam lingkungan kerja seperti jam kerja yang panjang, perjalanan yang jauh, beban pekerjaan.

Manusia tidak akan lepas dari tuntutan peran yang harus dijani dalam perkembangan hidupnya, demikian dengan buruh perempuan. Buruh perempuan memiliki peran istri dalam keluarga yaitu sebagai pendamping suami dan penerus keturunan. Sedangkan perannya sebagai ibu yaitu merawat, membimbing, serta mendidik anakanaknya tumbuh dewasa. Jika seorang buruh perempuan dapat menjalankan kedua peran tersebut secara optimal, maka perempuan tersebut di anggap sebagai makhluk sosial dan budaya yang utuh.

Selain itu Albrecht dalam Munandar (1985) mengatakan bahwa $80 \%$ perempuan mengajukan kebutuhan ekonomi sebagai motivasi untuk bekerja. Berdasarkan penjelasan tersebut dapat dikatakan bahwa banyaknya perempuan termasuk para ibu rumah tangga berpartisipasi dalam lapangan pekerjaan dengan jumlahnya yang semakin meningkat, bukan hanya didorong oleh terbukanya peluang kerja tetapi juga oleh dorongan ekonomi untuk mencapai tarap hidup yang lebih baik.

Konflik yang mungkin terjadi yaitu seringkali buruh perempuan memiliki tekanan dalam lingkungan kerja seperti jam kerja yang panjang, perjalanan yang jauh dan beban pekerjaan. Selain itu tekanan dalam keluarga yang mempengaruhi pekerjaan misalnya kehadiran anak yang masih kecil, lemahnya dukungan dari keluarga serta konflik keluarga.

Peran yang dimaksud adalah peran seorang perempuan sebagai istri bagi suaminya, ibu bagi anak-anaknya, dan peran sebagai perempuan yang 
memiliki karir di luar rumah. Buruh perempuan memiliki peran ganda sebagai istri dan ibu serta pencari nafkah.

Pekerjaan sosial yang dikemukakan oleh Charles Zastrow (1982), yang dikutip oleh Dwi Heru Sukoco (1995:7) sebagai berikut:

\begin{abstract}
"Pekerjaan sosial merupakan kegiatan profesional untuk membantu individu-individu, kelompok-kelompok dan masyarakat guna meningkatkan atau memperbaiki kemampuan mereka dalam berfungsi sosial serta menciptakan kondisi masyarakat yang memungkinkan mereka mencapai tujuan".
\end{abstract}

Berdasarkan pengertian di atas, seorang pekerja sosial harus bisa menciptakan kondisi masyarakat yang baik dan teratur dalam menjaga setiap keberfungsian elemennya yang menjadi para pemeran berbagai peran yang ada di dalam masyarakat. menciptakan kondisi masyarakat yang kondusif dengan relasi-relasi yang ada didalamnya untuk bisa memberikan keterikatan di antara para pemegang peran tersebut.

Terkait dengan peran buruh perempuan dalam keluarga, maka pekerja sosial harus mengidentifikasi kebutuhan klien dalam menjalankan peran-peran profesionalnya. Dapat dilakukan dengan menggunakan metode (social case work), metode tersebut dapat membantu klien individu berdasarkan pengetahuan, teknikteknik untuk membantu individu memecahkan masalah.

Pekerja sosial dapat berperan dalam memberikan pelayanan konsultasi kepada klien yang ingin mengungkapkan permasalahannya. Pekerja sosial harus menyadari permasalahannya serta melihat potensi dan kekuatan yang dimiliki klien. Pekerja sosial juga harus memberikan alternatif-alternatif pemecahan masalah.

\section{METODE}

Dengan demikian pendekatan kualitatif adalah pendekatan penelitian untuk memahami fenomena yang terjadi dalam sebuah masyarakat serta yang berkaitan dengan peran buruh perempuan dalam keluarga. Berdasarkan hal tersebut, untuk mendukung tercapainya tujuan penelitian, maka peneliti menggunakan pendekatan kualitatif. Sehingga dengan menggunakan pendekatan kualitatif akan lebih tepat dalam mendeskripsikan secara naratif, melakukan pengamatan, observasi dan wawancara yang dilakukuan peneliti di lapangan.

Teknik pengumpulan data merupakan suatu metode atau cara yang dilakukan peneliti dalam pengumpulan data, dengan melakukan wawancara mendalam, observasi, studi dokumentasi serta studi kepustakaan.

\section{PEMBAHASAN}

Seiring dengan meningkatnya pembangunan industri disetiap daerah, memicu seseorang untuk memperbaiki kehidupan dan meningkatkan kualitas hidup. Kini banyak perempuan yang berpartisipasi aktif bekerja di sektor publik untuk membantu memenuhi kebutuhan ekonomi keluarga.

Menurut Abdullah (2003 : 226), keterlibatan perempuan dalam industri rumah tangga dipengaruhi oleh beberapa faktor. Pertama, tekanan ekonomi. Kedua, lingkungan keluarga yang sangat mendukung dalam bekerja. Ketiga, tidak ada peluang kerja lain yang sesuai dengan ketrampilannya.

Berdasarkan penjelasan diatas, terdapat beberapa faktor pendorong keterlibatan perempuan dalam sektor industri yaitu dikarenakan tekanan ekonomi atau kebutuhan ekonomi keluarga yang semakin tak terjangkau, suami tidak bekerja, serta menambah pendapatan suami. Selain itu, rata-rata perempuan yang bekerja di sektor industri merupakan golongan ekonomi menengah ke bawah yang tingkat pendidikan dan keahliannya masih rendah.

Menurut (Denrich Suryadi, 2004:12), peran ganda adalah dua peran atau lebih yang di jalankan dalam waktu yang bersamaan. Peran yang dimaksud adalah peran seorang perempuan sebagai istri bagi suaminya, ibu bagi anakanaknya, dan peran sebagai perempuan yang memiliki karir di luar rumah. Sesuai dengan penjelasan diatas buruh perempuan yang bekerja di sektor industri akan dihadapkan dengan dua tuntutan peran, yaitu sebagai ibu rumah tangga 
dan sebagai pencari nafkah. Kedua peran tersebut merupakan kewajiban dan tanggung jawab yang harus dilakukan secara bersamaan dengan optimal.

Seringkali buruh perempuan mengalami konflik terkait keluarga dan pekerjaan. Menurut Greenhauss dan Beutell (1985) dalam Ella (2003:287-288), konflik peran ganda salah satunya adalah: Time Based Conflict, mengarah pada penggunaan waktu. Waktu untuk bekerja tidak dapat digunakan untuk melakukan kegiatan dalam rumah tangga. Seringkali buruh perempuan memiliki tekanan dalam keluarga yang mempengaruhi pekerjaan misalnya kehadiran anak yang masih kecil, lemahnya dukungan dari keluarga serta konflik keluarga. Selain itu dalam lingkungan kerja seperti jam kerja yang panjang, perjalanan yang jauh, beban pekerjaan.

Manusia tidak akan lepas dari tuntutan peran yang harus dijani dalam perkembangan hidupnya, demikian dengan buruh perempuan. Jika seorang buruh perempuan dapat menjalankan kedua peran tersebut secara optimal, maka perempuan tersebut di anggap sebagai makhluk sosial dan budaya yang utuh.

Untuk melaksanakan peran-perannya buruh perempuan dalam keluarga membutuhkan peran pekerja sosial dalam memberikan pelayanan konsultasi kepada klien yang ingin mengungkapkan permasalahannya. Selain itu dapat dilakukan family therapy yaitu sejenis terapi kelompok (group therapy) yang bertujuan untuk membantu keluarga yang memiliki masalah dengan interaksional, perilaku, dan emosi.

Menangani permasalahan peran buruh perempuan dalam keluarga, pekerja sosial memiliki peran sebagai enabler. Pekerja sosial dapat berperan sebagai pemercepat perubahan (enabler), seorang pekerja sosial membantu individu-individu, kelompok-kelompok dan masyarakat dalam mengakses sistem sumber yang ada, mengidentifikasi masalah dan mengembangkan kapasitasnya agar dapat mengatasi masalah untuk pemenuhan kebutuhannya.

\section{PENUTUP}

Keterlibatan buruh perempuan di sektor publik tidak sedikit diantaranya dipengaruhi oleh faktor ekonomi keluarga. Dalam menjalankan peran ganda tersebut sering kali buruh perempuan mengalami konfik secara peran serta perasaan.
Sebagai buruh perempuan tidak sepenuhnya dapat menjalankan peran sebagai istri dan ibu, sehingga dibutuhkan peran pekerja sosial untuk membantu buruh perempuan keluar dari permasalahan. Selain itu dalam melaksanakan peran-perannya buruh perempuan dalam keluarga membutuhkan peran pekerja sosial dalam memberikan pelayanan konsultasi kepada klient.

\section{DAFTAR PUSTAKA}

Desmaryanti, Elga. 2017. Peran Ganda Ibu Buruh Pabrik dalam Pola Asuh Anak. Melalui http://www.academia.edu/28716685/PE RAN_GANDA_IBU_BURUH_PABRI K_DALAM_POLA_ASUH_ANAK_C ONTOH_PROPOSAL_[diakses 13/07/2017]

Fahruddin, Muh. 2013.Jam Kerja di Indonesia Menurut Undang-Undang No.13 Tahun 2003 Tentang Ketenaga Kerjaan.

Melalui <http://mfahruddin8.blogspot.co.id/> [di akses 11 Juni 2017]

Raharjo, ST. 2015. Assessment untuk Praktik Pekerjaan Sosial dan Kesejahteraan Sosial. Bandung: Unpad Press 2015. Dasar Pengetahuan Pekerjaan Sosial. Bandung: Unpad Press. 2015. Keterampilan Pekerjaan Sosial: Dasar-dasar. Bandung, Unpad Press.

Risnawati. 2016. Peran Ganda Istri yang Bekerja dalam Membantu Ekonomi Keluarga Buruh Perkebunan Kelapa Sawit pada PT. BUMI MAS AGRO DI Kecamatan Sandaran Kabupaten Kutai Timur. http://ejournal.sos.fisip unmul.ac.id/site/wp content/uploads/2016/08/Jurnal\%20Ris nawati\%20(08-18-16-07-31-54).pdf

Septi, Dina. 2016. Buruh Perempuan dan Kawasan Industri: Rumah, Pabrik dan Serikat Buruh. http://majalahsedane.org/buruhperempuan-dan-kawasan-industri- 
rumah-pabrik-dan-serikat-buruh/

(diakses 11 Juni 2017)

Jumlah Pencari Kerja yang Terdaftar menurut Jenis Kelamin dan Tingkat Pendidikan yang Ditamatkan. Melalui $<$ https://subangkab.bps.go.id/linkTabel Statis/view/id/30> 